University of Nebraska - Lincoln

DigitalCommons@University of Nebraska - Lincoln

\title{
Trends in Precipitation, Streamflow, and Evapotranspiration in the Great Plains of the United States
}

J. Garbrecht

USDA-ARS

M. Van Liew

USDA-ARS, vanliew@windstream.net

G. O. Brown

Oklahoma State University

Follow this and additional works at: https://digitalcommons.unl.edu/usdaarsfacpub

Part of the Agricultural Science Commons

Garbrecht, J.; Van Liew, M.; and Brown, G. O., "Trends in Precipitation, Streamflow, and Evapotranspiration in the Great Plains of the United States" (2004). Publications from USDA-ARS / UNL Faculty. 462.

https://digitalcommons.unl.edu/usdaarsfacpub/462

This Article is brought to you for free and open access by the U.S. Department of Agriculture: Agricultural Research Service, Lincoln, Nebraska at DigitalCommons@University of Nebraska - Lincoln. It has been accepted for inclusion in Publications from USDA-ARS / UNL Faculty by an authorized administrator of DigitalCommons@University of Nebraska - Lincoln. 


\title{
Trends in Precipitation, Streamflow, and Evapotranspiration in the Great Plains of the United States
}

\author{
J. Garbrecht, M.ASCE${ }^{1}$; M. Van Liew, M.ASCE${ }^{2}$; and G. O. Brown, M.ASCE ${ }^{3}$
}

\begin{abstract}
Planning and strategic management of water resources are contingent on trends in water availability. In this study, the impact of decade-scale variations in annual and seasonal precipitation on streamflow and evapotranspiration (ET) were identified for 10 watersheds in Nebraska, Kansas, and Oklahoma. In the Great Plains, an upward trend in precipitation over the last two decades of the 20th Century had a strong impact on streamflow and a comparatively weaker impact on ET. Even though precipitation, streamflow, and ET amounts differed between watersheds, the trend due to the precipitation increase was similar for all watersheds. Increased precipitation led to a disproportionately large increase in streamflow and comparatively smaller increase in ET. On average, a $12 \%$ increase in annual precipitation led to a $64 \%$ increase in streamflow, but only a 5\% increase in ET. The seasonal partitioning of the annual precipitation increase was, in most cases, biased toward the fall, winter, and spring, with little or no change during the hot summer months. The strong streamflow response indicated that planning and management of surface-water storage and supply can be critically impacted by decadelong trends in precipitation. The lack of significant increase in precipitation and streamflow during summer suggests that any existing shortages will likely remain despite the observed annual precipitation increase. The ET response suggests that dryland farming and ecosystem vitality could benefit from the increased precipitation in fall, winter, and spring, but the relative impacts are more modest compared to the streamflow response and do not occur during summer when potential ET is greatest. Finally, since the mid-1990s precipitation and streamflow in a number of Oklahoma watersheds have shown a gradual decline from peak values in the late 1980s toward more average conditions. This declining trend in streamflow may be important for planning and management of water resources systems that must meet an increasing demand for water by a growing society while at the same time considering environmental and recreational needs.
\end{abstract}

DOI: 10.1061/(ASCE)1084-0699(2004)9:5(360)

CE Database subject headings: Climatic changes; Precipitation; Streamflow; Water resources; Surface waters; Watersheds; Regional analysis; Nebraska; Kansas; Oklahoma.

\section{Introduction}

Streamflow and evapotranspiration (ET) often reflect variations in precipitation at time scales from seasons to centuries and longer (NRC 1998). Seasonal and interannual climate variations are common occurrences, and society has built resilience to these variations. Water storage reservoirs are designed to bridge seasonal shortfalls of water, crop insurance program to help in the recovery from typical crop failures, and an elaborate transportation system to allow the rapid movement of relief supplies to areas stricken by unusual weather patterns. On the other hand, precipitation variations lasting decades or longer (decade-scale) have the potential to greatly surpass short-term variations in their societal, economic, and political impacts (Mantua et al. 1997;

\footnotetext{
${ }^{1}$ Research Engineer, USDA, ARS, Grazinglands Research Laboratory, 7202 W. Cheyenne, El Reno, OK 73036. E-mail: garbrech@grl.ars.usda.gov

${ }^{2}$ Research Hydrologist, USDA, ARS, Grazinglands Research Laboratory, 7202 W. Cheyenne, El Reno, OK 73036.

${ }^{3}$ Professor, Dept. of Biosystems and Agricultural Engineering, Oklahoma State Univ., Stillwater, OK 74078. E-mail: gbrown@okstate.edu

Note. Discussion open until February 1, 2005. Separate discussions must be submitted for individual papers. To extend the closing date by one month, a written request must be filed with the ASCE Managing Editor. The manuscript for this paper was submitted for review and possible publication on March 7, 2003; approved on December 19, 2003. This paper is part of the Journal of Hydrologic Engineering, Vol. 9, No. 5, September, 2004. @ASCE, ISSN 1084-0699/2004/5-360-367/\$18.00.
}

Woodhouse and Overpeck 1998). Even though decade-scale precipitation variations are subtler, it is the cumulative effects of sustained departures from average conditions that may lead to the greater impacts. For example, the 1987-1992 drought in California slowly depleted state water reserves and ultimately affected irrigated agriculture, urban water supply, reservoir operations, and natural ecosystems. Also, the decade-long wet period during the 1990s resulted in the substantial growth of Devils Lake near the Fort Totten Indian Reservation in northeastern North Dakota, flooded agricultural land, water-logged soils, and made low-lying farm roads increasingly impassable.

In many parts of the United States, annual precipitation is undergoing a slow change toward higher values (Karl et al. 1996; Karl and Knight 1998; Easterling et al. 2000). A similar trend has been observed in the Canadian Prairies where precipitation has increased over the last 75 years (Akinremi et al. 1999). Hu et al. (1998) detected a gradual increase in precipitation since the mid1960s in the Central United States, and Garbrecht and Rossel (2002) identified a marked increase over the last two decades of the 20th Century for many regions of the Great Plains. The importance of such decade-scale variations in precipitation on the hydrologic system and on various weather dependent segments of our society has been recognized in numerous studies (Mantua et al. 1997; Miles et al. 2000; Hotchkiss et al. 2000; Morehouse 2000). Lins and Slack (1999) found that streamflow trends in the contiguous United States were consistent with precipitation changes described by Karl and Knight (1998). Miles et al. (2000) 
successfully correlated seasonal streamflow responses of the Columbia River Basin with corresponding El Niño Southern Oscillation and Pacific Decadal Oscillation phases. Such continental and basin-scale investigations are important for the development of climate variation indices, identification of global change signals, determination of regional impacts, and assessment of changing risk of flood or drought conditions. However, the broadscale findings of these studies are not easily transferable to identify hydrologic impacts at the watershed scale, where many local water resources planning and management decisions are made. Also, the majority of watersheds in the United States have undergone modifications (land-use change, water conservation measures, dams, irrigation and urban water withdrawals, urbanization, river regulation, and flood control structures), which have undoubtedly affected streamflow regimes to an unknown degree (Changnon and Demissie 1996). Even if a trend in streamflow were observed, it is difficult, under these conditions, to conclusively attribute the trend to land use or to long-term precipitation variations.

In this study, the hydrologic impacts of decade-scale variations in precipitation are examined in more detail at the watershed scale. The objectives are to identify the sensitivity, magnitude, and range of changes in annual and seasonal streamflow and ET resulting from observed decade-scale precipitation variations. Midsized agricultural watersheds in the Great Plains with geographic and physiographic features well suited for this study were selected for investigation. First, the selected watersheds have undergone little land-use change, regulation, and urbanization over the last half-century. As a result, trends in watershed response can be more reliably tied to climate variations. Second, the east-west gradient of annual precipitation in the Great Plains is steep. This provides the opportunity to identify precipitation, streamflow, and ET relationships over a range of annual precipitation values. Third, in subhumid climates, watershed response, particularly streamflow, has been recognized to react sensitively to variations in precipitation (Garbrecht et al. 2001; McCarthy et al. 2001), thus providing favorable conditions to establish streamflowprecipitation relationships. Finally and most importantly, water in subhumid regions is often a limited resource and any sustained change in precipitation could result in tangible impacts on society, thus requiring a reassessment of water availability and utilization strategies. Findings of this study can provide insights and guidance to the effects of precipitation variations on surface-water resources and provide useful information for long-term planning and management of those water resources. On the agricultural sector, the magnitude and range of changes in ET as a result of precipitation variations can point to opportunities for increased productivity and potential for diversification, or the need for mitigating agronomic practices and developing supplemental water conservation measures.

\section{Data and Methodology}

Ten watersheds in Oklahoma, Kansas, and Nebraska that have mostly natural unregulated streamflow (Tortorelli 2002; Slack and Landwehr 1992; various state water agencies, personal communications, June 2002) were selected for analysis. Existing unregulated small dams and flood-retarding structures exist in many watersheds, however these structures only attenuate flood peaks and have little impact on annual and longer streamflow amount which is the focus of this study. Also, the selected watersheds are not subjected to extensive groundwater pumping for irrigation that

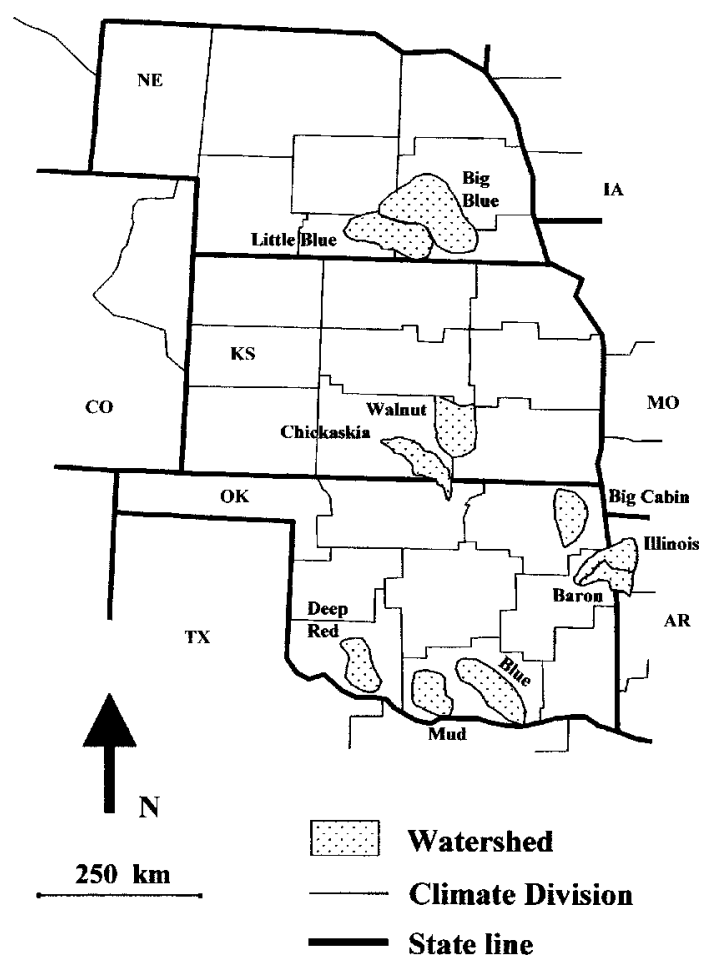

Fig. 1. Location map of watersheds

could have altered the streamflow and ET characteristics. The locations of the watersheds are shown in Fig. 1 and selected watershed attributes are listed in Table 1 . The size of the watersheds range from about $800 \mathrm{~km}^{2}$ (300 sq. mi.) to about $12,500 \mathrm{~km}^{2}$ (4,900 sq. mi.), and cover an east-west precipitation gradient ranging from about $1,220 \mathrm{~mm}$ (48 in.) in the east to about 700 $\mathrm{mm}$ (28 in.) in the west. Land-use information was provided by the state office of the National Resources Conservation Service (NRCS) in Oklahoma, Kansas, and Nebraska (Table 1). The predominant land use was grassland and pasture, followed by cropland and forest. Exceptions were the Deep Red Creek watershed with predominantly cropland, and the Illinois and Baron Fork watersheds with a high percentage of forest. The NRCS also provided the hydrologic soil group for each watershed, a qualitative parameter that identifies a watershed's runoff production potential. Hydrologic soil groups A and D have low and high runoff potential, respectively; and $\mathrm{B}$ and $\mathrm{C}$ are representative of moderate runoff production potential. Most watersheds in this study were classified as having moderate to high runoff production potential.

Streamflow data were obtained from the U.S. Geological Survey Web site (USGS 2001). For the Oklahoma and Kansas watersheds, records of registered surface and groundwater withdrawal for urban, industrial, and agricultural purposes was obtained from the Oklahoma Water Resources Board and the Division of Water Resources of the Kansas Department of Agriculture, respectively. The reported surface and groundwater withdrawals were less than $2 \%$ of the total streamflow for most watersheds, and for all practical purposes had little impact on streamflow. The Blue River is the exception with withdrawals of about $8 \%$ for the City of Durant and the Oklahoma State Fish Hatchery, primarily from surface flow. For the Oklahoma and Kansas watersheds, the reported amount of water withdrawn was added back to the streamflow to better approximate natural streamflow conditions. In the two Nebraska watersheds, most 
Table 1. Streamflow, Climate Division, and Precipitation Characteristics by Watershed

\begin{tabular}{|c|c|c|c|c|c|}
\hline \multirow{2}{*}{$\begin{array}{l}\text { Watershed } \\
\text { (USGS gauge number) }\end{array}$} & \multirow{2}{*}{$\begin{array}{l}\text { Drainage area } \\
\left(\mathrm{km}^{2}\right)\end{array}$} & \multirow{2}{*}{$\begin{array}{l}\text { Period of } \\
\text { streamflow }\end{array}$} & \multirow{2}{*}{$\begin{array}{c}\text { Mean } \\
\text { precipitation }^{\mathrm{a}} \\
(\mathrm{mm})\end{array}$} & \multirow{2}{*}{$\begin{array}{c}\text { Land use }^{\mathrm{b}} \\
(\%) \\
\mathrm{F} / \mathrm{G} / \mathrm{C} / \mathrm{O}\end{array}$} & \multirow{2}{*}{$\begin{array}{c}\begin{array}{c}\text { Hydologic } \\
\text { soil group }\end{array} \\
\mathrm{A} / \mathrm{B} / \mathrm{C} / \mathrm{D}\end{array}$} \\
\hline & & & & & \\
\hline $\begin{array}{l}\text { Blue Creek, Okla. } \\
(07332500)\end{array}$ & 1,232 & $1937-2001$ & 1,021 & 08/82/07/03 & $02 / 44 / 18 / 36$ \\
\hline $\begin{array}{l}\text { Mud Creek, Okla. } \\
(07315700)\end{array}$ & 1,480 & $1961-2001$ & 856 & $10 / 73 / 16 / 01$ & $07 / 74 / 04 / 15$ \\
\hline $\begin{array}{l}\text { Deep Red Creek, Okla. } \\
(07311500)\end{array}$ & 1,597 & $1950-2001$ & 733 & 01/35/63/01 & $00 / 18 / 03 / 79$ \\
\hline $\begin{array}{l}\text { Baron Fork, Okla. } \\
(07197000)\end{array}$ & 7,95 & $1949-2001$ & 1,124 & $47 / 49 / 02 / 02$ & $00 / 77 / 16 / 07$ \\
\hline $\begin{array}{l}\text { Illinois River, Okla. } \\
(07196500)\end{array}$ & 2,483 & $1936-2001$ & 1,112 & $52 / 39 / 01 / 08$ & $00 / 65 / 09 / 26$ \\
\hline $\begin{array}{l}\text { Big Cabin Creek, Okla. } \\
(07191000)\end{array}$ & 1,165 & $1948-2001$ & 1,014 & 08/72/15/05 & $00 / 30 / 36 / 34$ \\
\hline $\begin{array}{l}\text { Chickaskia River, Okla. } \\
(07152000)\end{array}$ & 4,813 & $1937-2001$ & 753 & 01/67/30/02 & $05 / 57 / 14 / 24$ \\
\hline $\begin{array}{l}\text { Walnut River, Kan. } \\
(07147800)\end{array}$ & 4,867 & $1922-2001$ & 814 & $02 / 75 / 20 / 03$ & $00 / 16 / 37 / 47$ \\
\hline $\begin{array}{l}\text { Big Blue River, Neb. } \\
(06882000)\end{array}$ & 1,1513 & $1932-2001$ & 736 & $02 / 10 / 86 / 02$ & $00 / 58 / 18 / 24$ \\
\hline $\begin{array}{l}\text { Little Blue River, Neb. } \\
(06884000)\end{array}$ & 6,084 & $1930-2001$ & 690 & $02 / 21 / 75 / 02$ & $02 / 71 / 22 / / 05$ \\
\hline
\end{tabular}

water withdrawals were from groundwater, i.e., the High Plains aquifer. Also, only water rights have been recorded by the State, not actual withdrawal amounts (G. Lindeman, Nebraska Dept. of Natural Resources, personal communication, 20 June 2002). Given this lack of information, no adjustments could be made to the streamflow for the Nebraska watersheds. The limitations of this approximation will be taken into consideration for results interpretation. Finally, streamflow values were expressed in terms of runoff depth to facilitate comparison with precipitation depth.

As for many rural areas in the Great Plains, the density of rain gauges with long-term records is low, and gauges are usually situated near towns where they are conveniently accessed for daily recording. Only a few gauges with long-term records were found within or in the immediate vicinity of the 10 watersheds selected for analysis. Furthermore, precipitation between climate stations that are 30 or more kilometers apart often show poor correlation. Hence, a regionally averaged precipitation was chosen to better represent regional and decade-long climate trends over each watershed. State divisional precipitation data were used to estimate seasonal and annual precipitation. State divisional precipitation data are spatially averaged monthly precipitation over a climate division and were obtained from the National Climatic Data Center (NCDC 1994; NCDC 2001). The historical origin and the calculation of divisional data can be found in Guttman and Quayle (1996). Climate divisions in Oklahoma, Kansas, and Nebraska cover an area of about 15,000 to $26,000 \mathrm{~km}^{2}$. The divisional precipitation data are well suited for this study because they bring out temporal, decade-long precipitation trends and variations that affect the entire region. The effects of spatial precipitation gradients and watershed location within a climate division are minimized by interpolation of neighboring climate division precipitation values to the center of the watersheds.
For the annual and longer time periods considered in this study, ET was calculated as the difference between precipitation and streamflow. Streamflow includes direct surface runoff, subsurface seepage return flow (interflow), and groundwater channel recharge. Since long-term groundwater and ET monitoring was not available for the selected watersheds, the net change in water storage within the watershed was assumed to average over a long period. In most cases, this is a realistic assumption because water storage, either in the soil profile or in the groundwater, fluctuates about a mean value and the net change over the years remains confined and small compared to cumulative precipitation, streamflow, and ET amounts over the same period. For example, a $2.0 \mathrm{~m}$ increase in average groundwater level over a 10 year period requires $160 \mathrm{~mm}$ of water (assuming an aquifer specific yield of $8 \%$ ). In a $700 \mathrm{~mm}$ precipitation zone and over a 10 year period, this $160 \mathrm{~mm}$ water depth corresponds to $2.3 \%$ of the total precipitation over the same period. Thus, the net change in water storage at decade-long timescales can be assumed negligible compared to cumulative precipitation, streamflow, and ET. Similarly, lag effects between precipitation and streamflow, while important at daily and monthly timescales, are less important at annual and decadal timescales. Finally, groundwater leaving the watershed as lateral subsurface flow was assumed to be small compared to streamflow and ET amounts and was neglected. These simplifying assumptions are consistent with the moderate to high runoff producing soils in the watersheds. These soils have low infiltration, slow percolation, and rapid surface runoff response, thus limiting storage and lag effects. With this simplified framework for long-term water budget considerations, all precipitation entering the watershed control-volume leaves as either streamflow or ET. For seasonal water budget considerations, the assumptions are somewhat less applicable, and their shortcomings and implica- 

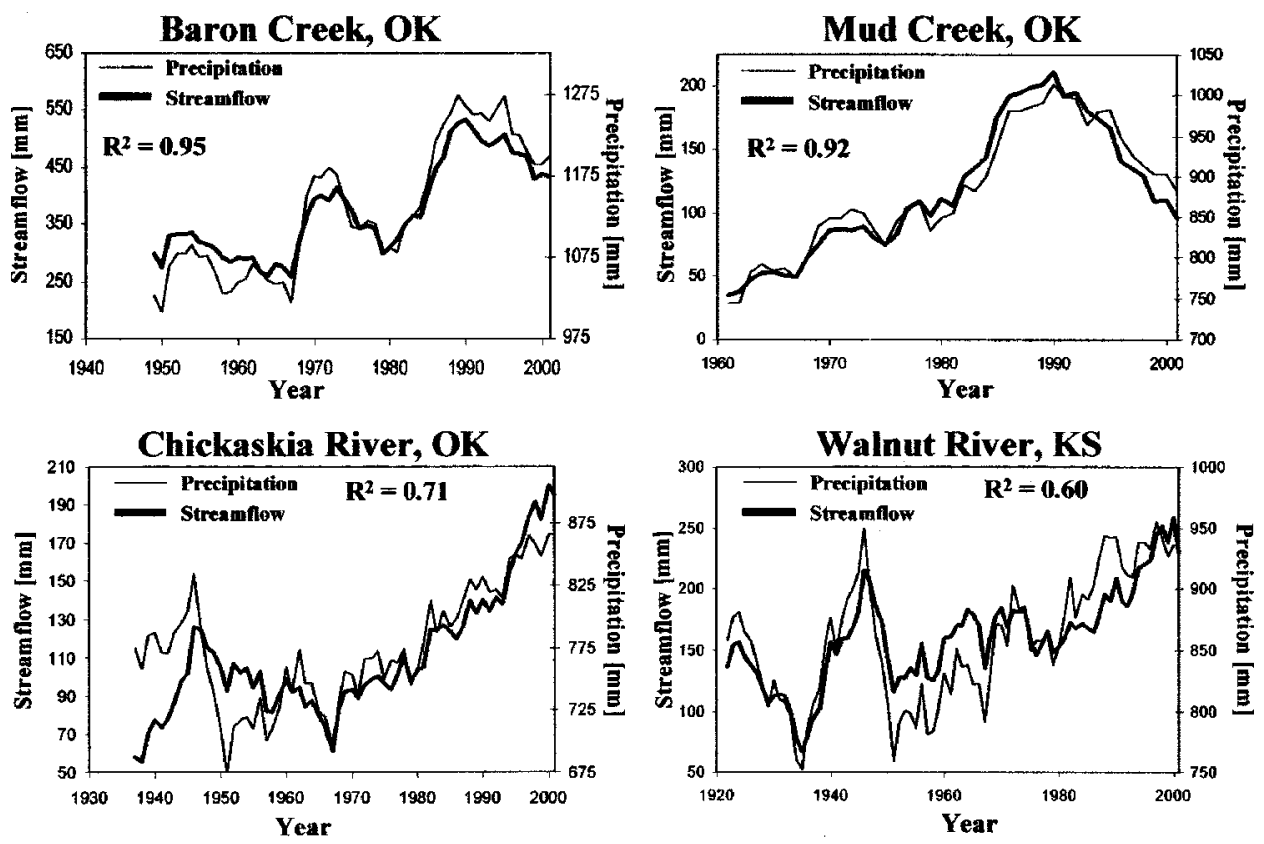

Fig. 2. Eleven year moving average of annual precipitation and streamflow for Mud Creek, Baron Fork, Chickaskia River, and Walnut River, and coefficient of determination between precipitation and streamflow values

tions are discussed in conjunction with the result interpretation.

Year-to-year variations in precipitation and streamflow are filtered and decade-scale variations are brought out by applying an 11 year moving average (MA) to the annual time series. For the 5 years on each end of the series, averages were computed for available years only. Visual inspection of the time series of the 11 year MAs and plots of cumulative departure of annual precipitation from the mean are used to identify decade-long wet and dry periods. For the identified decade-long wet and dry periods, the mean annual and seasonal precipitation, streamflow, and ET are calculated and compared to determine the magnitude, sensitivity, and range of change between the dry and wet periods. For the purpose of this study, winter is defined as January, February, and March; spring as April, May, and June; summer as July, August, and September, and fall as October, November, and December.

\section{Results}

The 11 year MA of the annual precipitation and streamflow shows a surprisingly high level of correlation. This is illustrated in Fig. 2 for Baron Fork, Mud Creek, Chickaskia River, and Walnut River, which are representative of the precipitation-streamflow behavior of the other seven watersheds. The coefficients of determination $\left(R^{2}\right)$ of the precipitation-streamflow regressions range from $0.6-$ 0.95 . Both precipitation and streamflow show depressed values in the 1950s, 1960s, and 1970s and elevated values in the 1980s and 1990s. The 1961-1980 period, termed the relative dry period, and the 1981-2001 period, termed the relative wet period, are used to illustrate differences in streamflow and ET. The beginning and ending years of the two periods are intentionally selected to be the same for all watersheds to provide an unbiased comparison between watersheds. While a number of years during the $1950 \mathrm{~s}$ could have been included for many of the watersheds, it was preferred to keep the length of the wet and dry period the same for all watersheds. The average annual precipitation, streamflow, and ET for each of the periods are given in Table 2.

\section{Precipitation}

The regional precipitation trend for each watershed is evaluated in this section. Precipitation increased for all watersheds during the 1981-2001 wet period. Mud Creek and Deep Red Creek in southcentral and southwestern Oklahoma experienced the greatest annual precipitation increase of about $19 \%$ over the dry period. The other five Oklahoma watersheds in northern and eastern Oklahoma experienced an increase around $12 \%$ over the dry period, whereas the watershed in Kansas experienced a 9\% increase, and the two Nebraska watersheds an increase just under $6 \%$. The average precipitation increase over all watersheds was about $12 \%$. With the exception of the two Nebraska watersheds, the precipitation increase in all watersheds was statistically significant (single-tailed $t$-test with unequal variance and significance level of 0.1 ). The consistency of the precipitation increase over such a large geographical area attests to the regional character of the precipitation trend. It is also noted that since the mid-1990s the 11 year MA precipitation trend for Baron Creek and Mud Creek (Fig. 2 ) is showing a gradual decline from the high values observed in the late 1980s. This decline is typical for many watersheds in southern and eastern Oklahoma.

\section{Streamflow}

For the geographic region under consideration, annual streamflow volume represents a small portion of the annual precipitation amount, between 8 and 34\%. Annual streamflow increased in all watersheds as a result of the decade-scale precipitation trend at the end of the 20th Century (Table 2). The magnitude of the streamflow increase was well correlated with the magnitude of the precipitation increase $\left(R^{2}=0.87\right)$, even though streamflow response depends on a combination of factors involving precipitation, land use, hydrologic soil group, ET, and other physiographic watershed variables. Also, the relative increase in streamflow from the dry to the wet period was always larger than the corresponding relative increase in precipitation. The two highest rela- 
Table 2. Average Annual Precipitation, Streamflow, and Evapotranspiration for Dry (1961-1980) and Wet Period (1981-2001) as a Result of Decade-Long Climate Variations and Difference between Dry and Wet Period in Percent

\begin{tabular}{|c|c|c|c|c|c|c|c|c|c|c|}
\hline \multirow{3}{*}{$\frac{\text { Watershed }}{\text { Blue Creek, Okla. }}$} & \multicolumn{2}{|c|}{$\begin{array}{l}\text { Average annual } \\
\text { precipitation } \\
\quad(\mathrm{mm})\end{array}$} & \multicolumn{2}{|c|}{$\begin{array}{l}\text { Average annual } \\
\text { streamflow } \\
(\mathrm{mm})\end{array}$} & \multicolumn{2}{|c|}{$\begin{array}{l}\text { Average annual } \\
\mathrm{ET}^{\mathrm{a}} \\
(\mathrm{mm})\end{array}$} & \multirow{2}{*}{\multicolumn{2}{|c|}{$\begin{array}{l}\text { Average runoff and } \\
\text { retention ratio }\end{array}$}} & \multirow{3}{*}{$\begin{array}{c}\begin{array}{c}\text { Streamflow to } \\
\text { precipitation sensitivity }\end{array} \\
3.3\end{array}$} & \multirow{3}{*}{$\begin{array}{c}\begin{array}{c}\text { ET to precipitation } \\
\text { sensitivity }\end{array} \\
0.5\end{array}$} \\
\hline & \multirow{2}{*}{$\begin{array}{c}\text { Dry } \\
972 \\
(\Delta 152)\end{array}$} & \multirow{2}{*}{$\begin{array}{c}\text { Wet } \\
1124 \\
(15.6 \%)\end{array}$} & \multirow{2}{*}{$\begin{array}{c}\text { Dry } \\
210 \\
(\Delta 92)\end{array}$} & \multirow{2}{*}{$\begin{array}{c}\text { Wet } \\
302 \\
(43.8 \%)\end{array}$} & \multirow{2}{*}{$\begin{array}{c}\text { Dry } \\
762 \\
(\Delta 60)\end{array}$} & \multirow{2}{*}{$\begin{array}{c}\text { Wet } \\
822 \\
(7.9 \%)\end{array}$} & & & & \\
\hline & & & & & & & 0.24 & 0.76 & & \\
\hline Mud Creek, Okla. & $\begin{array}{c}\Delta 806 \\
(\Delta 149)\end{array}$ & $\begin{array}{c}955 \\
(18.5 \%)\end{array}$ & $\begin{array}{c}65 \\
(\Delta 100)\end{array}$ & $\begin{array}{c}165 \\
(153.8 \%)\end{array}$ & $\begin{array}{c}741 \\
(\Delta 49)\end{array}$ & $\begin{array}{c}790 \\
(6.6 \%)\end{array}$ & 0.13 & 0.87 & 8.3 & 0.4 \\
\hline Deep Red Creek, Okla. & $\begin{array}{c}693 \\
(\Delta 138)\end{array}$ & $\begin{array}{c}831 \\
(19.9 \%)\end{array}$ & $\begin{array}{c}53 \\
(\Delta 98)\end{array}$ & $\begin{array}{c}151 \\
(184.9 \%)\end{array}$ & $\begin{array}{c}640 \\
(\Delta 40)\end{array}$ & $\begin{array}{c}680 \\
(6.3 \%)\end{array}$ & 0.13 & 0.87 & 9.3 & 0.3 \\
\hline Baron Fork, Okla. & $\begin{array}{c}1,072 \\
(\Delta 148)\end{array}$ & $\begin{array}{c}1,220 \\
(13.8 \%)\end{array}$ & $\begin{array}{c}315 \\
(\Delta 143)\end{array}$ & $\begin{array}{c}458 \\
(45.4 \%)\end{array}$ & $\begin{array}{l}757 \\
(\Delta 5)\end{array}$ & $\begin{array}{c}762 \\
(0.6 \%)\end{array}$ & 0.34 & 0.66 & 3.3 & 0.0 \\
\hline Illinois River, Okla. & $\begin{array}{c}1,068 \\
(\Delta 128)\end{array}$ & $\begin{array}{c}1,196 \\
(12.9 \%)\end{array}$ & $\begin{array}{c}310 \\
(\Delta 84)\end{array}$ & $\begin{array}{c}394 \\
(27.1 \%)\end{array}$ & $\begin{array}{c}758 \\
(\Delta 44)\end{array}$ & $\begin{array}{c}802 \\
(5.8 \%)\end{array}$ & 0.31 & 0.69 & 2.1 & 0.4 \\
\hline Big Cabin Creek, Okla. & $\begin{array}{c}981 \\
(\Delta 120)\end{array}$ & $\begin{array}{c}1,101 \\
(12.2 \%)\end{array}$ & $\begin{array}{c}245 \\
(\Delta 85)\end{array}$ & $\begin{array}{c}330 \\
(34.7 \%)\end{array}$ & $\begin{array}{c}736 \\
(\Delta 35)\end{array}$ & $\begin{array}{c}771 \\
(4.8 \%)\end{array}$ & 0.28 & 0.72 & 2.8 & 0.4 \\
\hline Chickaskia River, Okla. & $\begin{array}{c}739 \\
(\Delta 91)\end{array}$ & $\begin{array}{c}830 \\
(12.3 \%)\end{array}$ & $\begin{array}{c}88 \\
(\Delta 63)\end{array}$ & $\begin{array}{c}151 \\
(71.6 \%)\end{array}$ & $\begin{array}{c}651 \\
(\Delta 28)\end{array}$ & $\begin{array}{c}679 \\
(4.3 \%)\end{array}$ & 0.15 & 0.85 & 5.8 & 0.3 \\
\hline Walnut River, Kan. & $\begin{array}{c}812 \\
(\Delta 70)\end{array}$ & $\begin{array}{c}882 \\
(8.6 \%)\end{array}$ & $\begin{array}{c}162 \\
(\Delta 41)\end{array}$ & $\begin{array}{c}203 \\
(25.3 \%)\end{array}$ & $\begin{array}{c}650 \\
(\Delta 29)\end{array}$ & $\begin{array}{c}679 \\
(4.5 \%)\end{array}$ & 0.22 & 0.78 & 2.9 & 0.5 \\
\hline Big Blue River, Neb. & $\begin{array}{c}732 \\
(\Delta 43)\end{array}$ & $\begin{array}{c}775 \\
(5.9 \%)\end{array}$ & $\begin{array}{c}61 \\
(\Delta 23)\end{array}$ & $\begin{array}{c}84 \\
(37.7 \%)\end{array}$ & $\begin{array}{c}671 \\
(\Delta 20)\end{array}$ & $\begin{array}{c}691 \\
(3.0 \%)\end{array}$ & 0.10 & 0.90 & 6.4 & 0.5 \\
\hline Little Blue River, Neb. & $\begin{array}{c}687 \\
(\Delta 40)\end{array}$ & $\begin{array}{c}727 \\
(5.7 \%)\end{array}$ & $\begin{array}{c}53 \\
(\Delta 10)\end{array}$ & $\begin{array}{c}63 \\
(18.9 \%)\end{array}$ & $\begin{array}{c}634 \\
(\Delta 30)\end{array}$ & $\begin{array}{c}664 \\
(4.7 \%)\end{array}$ & 0.08 & 0.92 & 3.3 & 0.8 \\
\hline Mean change & $\Delta 108$ & $12 \%$ & $\Delta 74$ & $64 \%$ & $\Delta 36$ & $5 \%$ & 0.20 & 0.80 & 4.8 & 0.4 \\
\hline
\end{tabular}

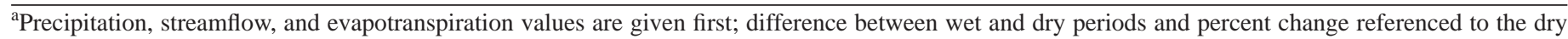
period are given in parentheses.

tive streamflow increases ( $150 \%$ and above) were observed in two watersheds in south-central and southwestern Oklahoma. The high values for the percentage resulted in part from relating streamflow change to a low annual streamflow reference value. The average relative streamflow increase over all watersheds was 64\%. For Baron Creek and Mud Creek, the observed gradual decline in the 11 year MA precipitation at the end of the $1990 \mathrm{~s}$ was well reflected in the corresponding streamflow values (Fig. 2). These declining streamflow values may be important for planning and management of water resources that must meet increasing municipal, industrial, environmental, and recreational demands.

The sensitivity of streamflow to variations in precipitation was measured by the ratio of the relative increase of streamflow over relative increase of precipitation. The streamflow-precipitation sensitivity for the 10 watersheds ranged from 2.1-9.3, meaning that a percentage change in precipitation always resulted in a larger percentage change in streamflow. The average streamflowprecipitation sensitivity was 4.8 . The increase in streamflow between the dry and wet periods was found to be statistically significant (single-tailed $t$-test with unequal variance and significance level of $p=0.10$ ) for all watersheds in Oklahoma and for the Big Blue River in Nebraska ( $p$-values were 0.02, $<0.01$, $<0.01,<0.01,0.06,0.06,<0.01$, and 0.06 for the Blue Creek, Mud Creek, Deep Red Creek, Baron Fork, Illinois River, Big Cabin Creek, Chickashia River, and Big Blue River, respectively). The increase was not statistically significant for the Walnut River in Kansas ( $p$-value $=0.17$, even though the corresponding precipitation change was significant $(p$-value $=0.08)$, and it was not significant for the Little Blue River in Nebraska ( $p$-value $=0.18$ ).
The $p$-values are listed here only to provide the reader with a general impression of the level of the significance.

\section{Evapotranspiration}

Assuming ET is the complement of runoff, 66 to $90 \%$ of the annual precipitation contributed to ET, and the increasing precipitation trend between dry and wet period led to an increased ET for all watersheds (Table 2). For watersheds in the drier precipitation zone (under $900 \mathrm{~mm}$ ) the average increase in ET was well correlated to average increase in precipitation. However, for watersheds in the higher precipitation zone (above $900 \mathrm{~mm}$ ) the correlation was lower, mainly because a larger portion of the precipitation increase contributed to streamflow, thus reducing the signal to noise ratio for ET. The average relative increase in ET over all watersheds from the dry to the wet period was about $5 \%$ and was found to be statistically significant for only 4 out of the 10 watersheds (single-tailed $t$-test with unequal variance and significance level of 0.1 ). The ET-precipitation sensitivity for the 10 watersheds ranged for 0.0 to 0.8 . These sensitivity values are below 1.0 and imply that an increase in precipitation always resulted in a smaller percent increase in ET. The average ETprecipitation sensitivity was 0.4 and reflected a low sensitivity of ET to changes in precipitation.

\section{Precipitation-Streamflow-Evapotranspiration Relationship}

Relative increases in precipitation, streamflow, and ET hint at a strong impact of decade-scale precipitation change (12\% in- 


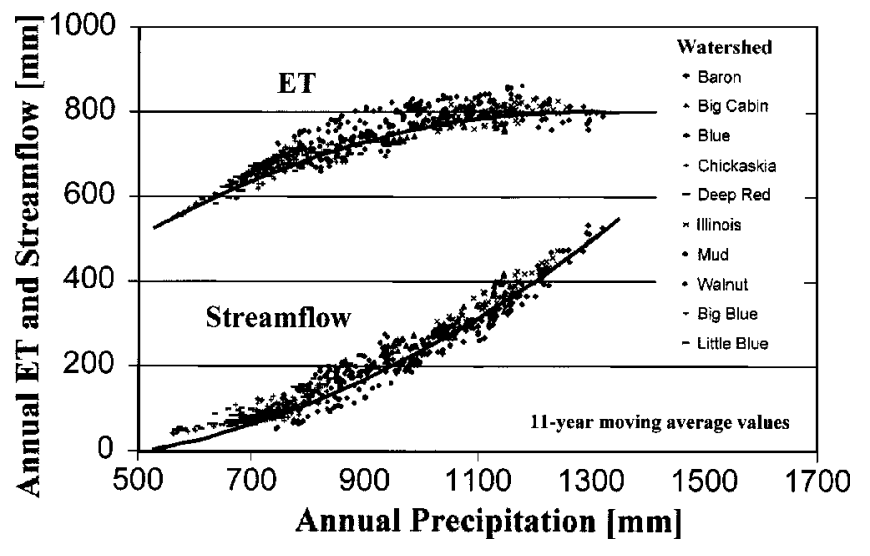

Fig. 3. Precipitation-streamflow-ET relationship for 10 watersheds and based on 11 year moving average annual values

crease) on streamflow (64\% increase) and a weak impact on ET (5\% increase). The same holds true when considering actual precipitation, streamflow, and ET amounts. On average over all watersheds, precipitation increased by $103 \mathrm{~mm}$, of which the larger share $(68 \mathrm{~mm})$ went to streamflow and the smaller share $(35 \mathrm{~mm})$ to ET. However, these average values only suggest general tendencies for the region under consideration and do not give justice to the true complexity and range of variations of the precipitationstreamflow-ET relationship at the watershed scale.

The interplay between precipitation, streamflow, and ET is best illustrated by considering a plot of 11 year MA annual streamflow and ET versus corresponding annual precipitation for all 10 watersheds (Fig. 3). The pattern of the precipitationstreamflow-ET relationship is consistent across all watersheds. Streamflow depth is always less than ET depth. The difference between streamflow and ET depth is large in the low precipitation areas and smaller in areas with higher precipitation. The precipitation-streamflow relationship is flat for low precipitation values, becomes increasingly steeper with increasing precipitation, and approaches a one-to-one slope for annual precipitation values above $900 \mathrm{~mm}$. On the other hand, the pattern of the precipitation-ET relationship is the opposite of the precipitationstreamflow relationship: it is nearly a one-to-one slope for low precipitation values, flattens gradually with increasing precipitation, and approaches a constant $800 \mathrm{~mm}$ for annual precipitation above $900 \mathrm{~mm}$. It is also noted that the ET and streamflow values for the two Kansas watersheds are well in line with the data of the Oklahoma and Kansas watersheds. Thus, the previously discussed assumption regarding the accounting of water withdrawals does not appear to have been an important factor in identifying streamflow response to long-term precipitation variations.

Based on these precipitation-streamflow-ET relationships the following inferences can be drawn: (1) In low precipitation regions and during dry periods (below $750 \mathrm{~mm}$ ), a large portion of the precipitation variation goes to ET and a small portion to streamflow. However, the small portion of precipitation variation going to streamflow may be large compared to existing low streamflow and may lead to a large relative increase in streamflow; (2) in high precipitation regions and during wet periods (above $900 \mathrm{~mm}$ ), the largest portion of the precipitation variation goes to streamflow and a small portion goes to ET - considering the high initial value of the ET, this small addition only produces a modest relative change in ET; and (3) for the precipitation zone between $750 \mathrm{~mm}$ and $900 \mathrm{~mm}$, both streamflow and ET receive roughly an equal fraction of the precipitation. However, because of the comparatively low streamflow and comparatively high ET, the relative change is larger for streamflow than for ET, hence, the strong impact of decade-scale precipitation variations on streamflow.

This analysis was conducted on annual precipitation, streamflow, and ET values for all watersheds, and reflects the general behavior of watersheds. For watershed specific relationships, each watershed must be evaluated and interpreted individually. Such an analysis has shown that most watersheds do indeed follow relationships similar to the ones discussed, even though the trend line for both ET and streamflow may be shifted and more curved than the ones shown in Fig. 3.

\section{Seasonality of Precipitation, Streamflow and Evapotranspiration}

Seasonal distribution of decade-scale changes in precipitation, streamflow, and ET is as important as annual changes, because seasonal patterns of water availability (precipitation and streamflow) often differ from seasonal water needs, which in turn may require management intervention to balance differences in availability and need. For example, peak urban and agricultural water needs are often during the summer, yet precipitation increases may not occur during that season, and management intervention may be required to use out-of-season water to meet summer needs. For the southern and central Great Plains, seasonal distribution of precipitation varied along a north-south axis. Therefore, the seasonal distribution of changes in precipitation, streamflow, and ET for the 10 watersheds was reviewed from north to south. Fig. 4 shows the seasonal amounts and changes of precipitation, streamflow, and ET for the dry (1961-1980) and wet (19812001) periods for the Big Blue River, Walnut River, Baron Creek, and Mud Creek.

For the Big Blue River watershed, about $70 \%$ of the annual precipitation was in spring and summer. About half of the increase in annual precipitation in the wet period occurred during the spring, while the other half was about evenly distributed between summer, fall, and winter [Fig. 4(a)]. Thus, spring, the wettest season of the year, captured the lion's share of the annual precipitation increase, and the warmer summer and drier fall and winter saw smaller increases. Streamflow increased about equally in spring and summer with no increase in fall and winter. The summer increase was attributed in part to a lag in runoff from the spring precipitation increase. Even though the streamflow increase in spring and summer was small in terms of depth (on average $12.5 \mathrm{~mm}$ ), it represented a sizable relative increase (on average $75 \%$ ). With respect to ET, half the annual increase occurred in spring concurrently with the precipitation increase. The other half occurred in fall and winter. The spring, fall, and winter increase in ET was small in terms of depth (on average $7 \mathrm{~mm}$ ) and in terms of relative size (on average $7 \%$ ). The small decrease in ET during the summer was believed to be artificial and related to the spring-to-summer streamflow lag, as well as the simplification in the calculation of ET that assumed no lag. The pattern of seasonal precipitation, streamflow, and ET was essentially identical for the neighboring Little Blue River. A more precise accounting of direct runoff, lagged subsurface return flow, and ET requires computer simulation, which is outside the scope of this study.

For the Walnut River watershed, spring and summer received about $65 \%$ of the annual precipitation. The precipitation increase due to the wet period was about evenly distributed over the fall, winter, and spring, with no relevant change during summer [Fig. 
Big Blue River

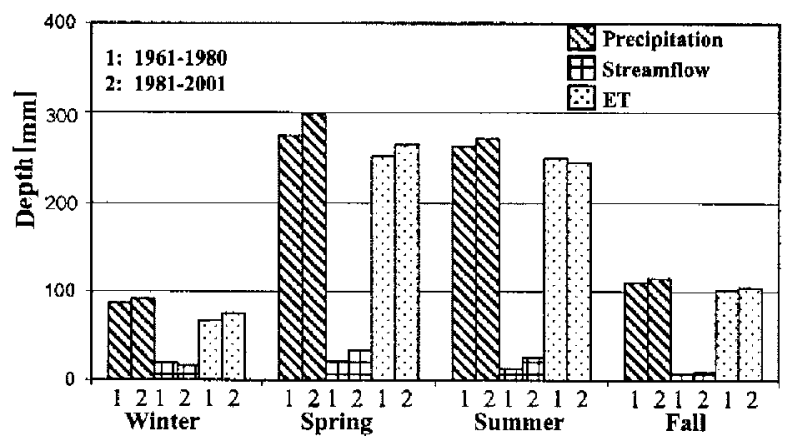

Baron Fork River

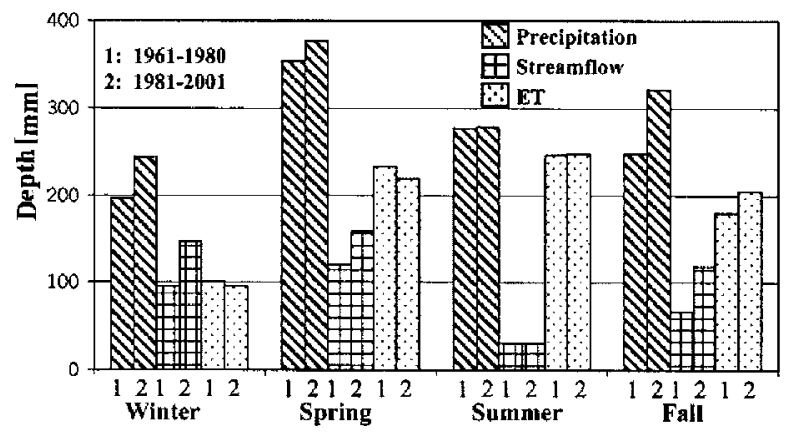

Walnut River

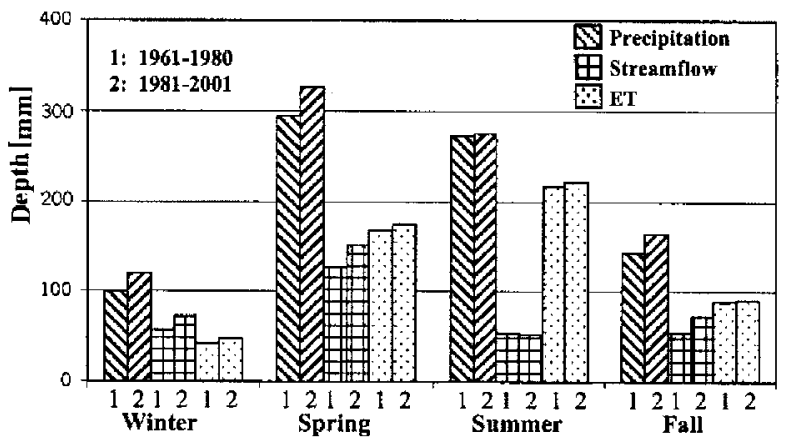

Mud Creek

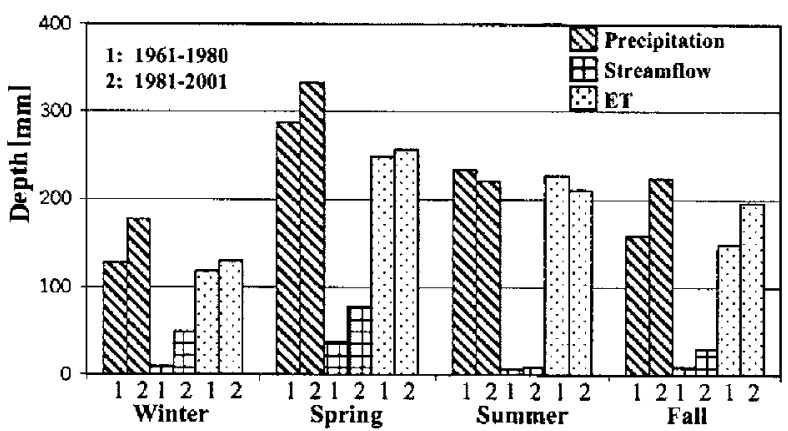

Fig. 4. Differences in the seasonal distribution of precipitation, streamflow, and evapotranspiration between the dry (1961-1980) and wet (1981-2001) periods

4(b)]. The dry fall and winter seasons captured a little over half of the annual precipitation increase, whereas spring captured the remainder and summer saw no change. The seasonal changes for streamflow was distributed similarly to that of precipitation; in winter, spring, and fall, streamflow increased by 32,18 , and $30 \%$, respectively, whereas summer saw a slight decrease $(-8 \%)$. Increases in ET were minimal, about 9, 5, and 3\% in winter, spring, and summer, respectively. For the Chickaskia River, the patterns were also similar for fall, winter, and spring. The summer precipitation and ET decreased slightly ( -2 and $-6 \%$, respectively), while the low summer streamflow increased by about $90 \%$, mostly as a result of runoff lag from higher spring precipitation. The summer decrease in ET was believed to be mostly artificial for reasons given earlier.

For Baron Creek watershed, the low and high precipitation seasons are winter and spring, respectively [Fig. 4(c)]. Fall captured about half the annual increase in precipitation from the wet period, while winter captured another third, and spring the remainder. Summer remained unchanged. Hence, fall and winter together captured about $80 \%$ of the annual precipitation increase. Streamflow increased about the same amount in winter, spring, and fall (on average $46 \mathrm{~mm}$ or 52\%) with no change during the summer. ET remained somewhat equal during winter and summer and increased during the fall. The slight decrease in ET during spring was again attributed to runoff lag effects and simplified ET calculations. Nevertheless, the overall trend in ET was clear-it increased only in fall by a sizable amount $(25 \mathrm{~mm}$ or $14 \%)$. One reason that ET did not increase during winter and spring even though precipitation increased was that the watershed is in a higher precipitation region (over 1,000 $\mathrm{mm}$ annual precipitation), the warm season grasses are dormant, and most additional precipitation in the cool winter and spring left the watershed as streamflow. The seasonal patterns for the Illinois River, Big Cabin Creek, and Blue River were similar, with a slight decrease in precipitation and ET during summer.

Finally, for the Mud Creek watershed, the wet season is spring, and precipitation decreases gradually thereafter from summer to fall to winter. Mud Creek was one of the watersheds that experienced the highest annual increase in precipitation (18\%) during the wet period. This increase was evenly distributed over the fall, winter, and spring, whereas summer saw a slight decrease. The average precipitation increase during fall, winter, and spring was sizable (on average $54 \mathrm{~mm}$ or $32 \%$ ). Thus, the two driest seasons (fall and winter) of the year benefited the most from the precipitation increase. Streamflow displayed a similar seasonal distribution, with fall, winter, and spring flows increasing by over $100 \%$, whereas summer low-flows remained essentially unchanged. ET increased mostly in fall (47 $\mathrm{mm}$ or $32 \%$ ) and to a lesser amount in winter and spring. The decrease in ET during the summer is primarily related to the decrease in summer precipitation, with some possible contribution related to the previously discussed lag effect. A similar seasonal distribution pattern for precipitation, streamflow, and ET applied to Deep Red Creek.

\section{Conclusions}

The central Great Plains experienced a decade-scale precipitation increase at the end of the 20th Century. This study examined the annual and seasonal impact of this precipitation trend on streamflow and ET for 10 watersheds in Nebraska, Kansas, and Oklahoma. Average annual precipitation increased between 6 and 20\% with smaller values applying to the northern watersheds and larger values to the southern watersheds. The seasonal partition- 
ing of this increase was in most cases biased toward the fall, winter, and spring with little change during summer. The increase in streamflow amounts resulting from the precipitation trend were mostly modest for watersheds that have annual precipitation less than $700 \mathrm{~mm}$, even though the relative increases in streamflow were substantial, ranging from 50 to over $150 \%$. For those watersheds with annual precipitation above $900 \mathrm{~mm}$, the increase in streamflow amounts was a more substantial portion of the precipitation increase, and the relative increase ranged between 20 and $40 \%$. Evapotranspiration (ET), a large portion of precipitation, increased primarily in the dry western watersheds whereas in the wet eastern watersheds most of the additional precipitation contributed to streamflow. Also, for many Oklahoma watersheds, a recent gradual decline in precipitation trend from the high values of the late 1980s was observed. The seasonal pattern of ET was much less consistent and more difficult to interpret. In general, ET appears to increase in the spring for the northern watersheds and in the fall for southern watersheds. However, the relative increase in ET was modest (generally less than 10\%) and sometimes ambiguous due to the simplifying assumption underlying the calculation of ET. The following inferences can be drawn from the findings of this study:

- High water demand by agricultural and urban areas during the summer months did not directly benefit from the decade-scale trend of precipitation. Precipitation deficits during the hot season endured, and available summer water supply remained limited to existing storage capacity.

- Most of the precipitation fueled ET. Fall and winter crops, cool season grasses, and winter wheat-grazing opportunities stood to benefit from the precipitation trend. Summer crops and warm season grasses only benefited from additional spring moisture stored in the soil.

- Streamflow and ET impacts of decade-scale precipitation trends were viewed as an indication of changes one could encounter under climate change scenarios, this study suggested that the greatest impact of a wetter or a drier climate in the Great Plains could be expected during fall, winter, and spring, but not necessarily during summer, and the most notable impact would be on streamflow.

- Long-term ET and groundwater measurements are generally not available for watersheds to conduct decade-scale trend analyses. Watershed specific impacts of response-lag and watershed storage, which were assumed negligible in this study because of the year-long need to be confirmed through numerical watershed modeling, especially at the seasonal timescale.

The strong impacts of decade-long precipitation variations on streamflow emphasize the importance of including such information in planning and strategic management of water resources. This may be particularly relevant if the recently observed declining trend in decade-scale precipitation and streamflow in the Oklahoma watersheds over the last few years persists because existing management of the water supply system has attuned itself to several decades of prevalently wet conditions.

\section{References}

Akinremi, O. O., McGinn, S. M., and Cutfirth, H. W. (1999). "Precipitation trends on the Canadian prairies." J. Clim., 12, 2996-3003.

Changnon, S. A., and Demissie, M. (1996). "Detection of changes in streamflow and floods resulting from climate fluctuations and land use-drainage changes." Clim. Change, 32, 411-421.
Easterling, D. R., Evans, J. L., Groisman, P. Y., Karl, T. R., Kunkel, K. E., and Ambenje, P. (2000). "Observed variability and trends in extreme climate events: A brief review." Bull. Am. Meteorol. Soc., 81(3), 417425.

Garbrecht, J., and Rossel, F. E. (2002). "Decade-scale precipitation increase in Great Plains at end of 20th century." J. Hydrologic Eng., 7(1), 64-75.

Garbrecht, J., Rossel, F. E., and Schneider, J. M. (2001). "Decade-scale precipitation and streamflow variation in the Kansas-Nebraska region." Proc., 12th Symp. on Global Change and Climate Variations, 81st American Meteorological Society Ann. Meeting, AMS, Boston, 319-321.

Guttman, N. B., and Quayle, R. G. (1996). "A historical perspective of U.S. climate divisions.” Bull. Am. Meteorol. Soc., 77(2), 293-303.

Hotchkiss, R. H., Jorgensen, S. F., Stone, M. C., and Fontaine, T. A. (2000). "Regulated river modeling for climate change impact assessment: The Missouri River." J. Am. Water Resour. Assoc., 36(2), 375386.

Hu, Q., Woodruff, C. M., and Mudrick, S. E. (1998). "Interdecadal variations of annual precipitation in the Central United States." Bull. Am. Meteorol. Soc., 79(2), 221-229.

Karl, T. R., and Knight, R. W. (1998). "Secular trends of precipitation amount, frequency, and intensity in the United States." Bull. Am. Meteorol. Soc., 79(2), 231-241.

Karl, T. R., Knight, R. W., Easterling, D. R., and Quayle, R. G. (1996). "Indices of climate change for the United States." Bull. Am. Meteorol. Soc., 77(2), 279-292.

Lins, H. F., and Slack, J. R. (1999). "Streamflow trends in the Unites States." Geophys. Res. Lett., 26(2), 227-230.

Mantua, N. J., Hare, S. R., Zhang, Y., Wallace, J. M., and Francis, R. C. (1997). "A Pacific interdecadal climate oscillation with impacts on salmon production." Bull. Am. Meteorol. Soc., 78(6), 1070-1079.

McCarthy, J. J., Canziani, O. F., Leary, N. A., Dokken, D. J., and White, K. S., eds. (2001). "Climate change 2001, impacts, adaptation and vulnerability." Intergovernmental Panel on Climate Change (IPCC) Working Group II, Cambridge University Press, New York.

Miles, E. L., Snover, A. K., Hamlet, A. F., Callahan, B., and Fluharty, D. (2000). "Pacific Northwest regional assessment: The impacts of climate variability and climate change on the water resources of the Columbia River Basin." J. Am. Water Resour. Assoc., 36(2), 399-420.

Morehouse, B. J. (2000). "Climate impacts on urban water resources in the Southwest: The importance of context." J. Am. Water Resour. Assoc., 36(2), 265-277.

National Climate Data Center (NCDC). (1994). "Time bias corrected divisional temperature-precipitation-drought index." Data Set TD9640, NCDC, Asheville, N.C., 12.

NCDC. (2001). Climate division: Temperature-precipitation-drought data, 〈http://www.ncdc.noaa.gov/oa/climate/onlineprod/drought/ ftppage.html (June 19, 2002).

National Research Council (NRC). (1998). "Decade-to-century-scale climate variability and change, A science strategy." Panel on Climate Variability on Decade-to-Century Time Scales; Board on Atmospheric Sciences and Climate; Commission on Geosciences, Environment, and Resources, Washington, D.C., 141.

Slack, J. R., and Landwehr, J. M. (1992). "Hydro-climatic data network: A U.S. geological survey streamflow data set for the United States for the study of climate variations, 1874-1988." USGS Open-File Rep. 92-129, 〈http://water.usgs.gov/pubs/of/ofr92-129/content.html〉 (July $8,2002)$.

Tortorelli, R. L. (2002). "Statistical summaries of streamflow in Oklahoma through 1999." U.S. Geological Survey Water-Resources Investigations Rep. 02-4025, USGS, Reston, VA., 510.

United States Geological Survey (USGS). (2001). "Water resources of the United States, historical NWIS-W data." U.S. Geological Survey, 〈http://waterdata.usgs.gov/nwis〉 (August 6, 2002).

Woodhouse, C. A., and Overpeck, J. T. (1998). "2000 years of drought variability in the Central United States." Bull. Am. Meteorol. Soc., 79(12), 2693-2714. 